\title{
FUNGSI KESANTUNAN BERBAHASA DALAM INTERAKSI GURU DAN MURID DI LINGKUNGAN MIS AL JIHAD PALANGKA RAYA
}

\author{
Function of Language Politeness in Interaction between Teachers and Students \\ at MIS Al Jihad Palangka Raya
}

\author{
*Lilik Kholisotin, \& Lastaria \\ Madrasah Ibtidaiyah Education Study Program, Universitas Muhammadiyah Palangkaraya, RTA Milono St. Km.1,5 \\ Palangka Raya, Indonesia \\ *e-mail : lilikbadir@yahoo.com
}

\begin{abstract}
ABSTRAK
Kesantunan bahasa merupakan tatacara untuk tidak menimbulkan kesan yang buruk kepada lawan bicara atau tatakrama letika berbahasa. Rumusan masalah dalam penelitian ini ialah: (1) Bagaimana fungsi kesantunan berbahasa dalam interaksi guru dan siswa di lingkungan MIS AI Jihad Palangka Raya? Penelitian ini bertujuan untuk mendeskripsikan fungsi kesantunan berbahasa dalam interaksi guru dan siswa di lingkungan MIS Al Jihad Palangka Raya. Pendekatan yang digunakan dalam penelitian ialah pendekatan pragmatis yang mana pendekatan ini cocok untuk memahami pemakaian bahasa. Jenis penelitian yang digunakan adalah kualitatif. Sedangkan, metode penelitian ialah deskriptif bertujuan untuk memperoleh informasi-informasi mengenai keadaan dan melihat kaitannya dengan variable-variabel yang telah ditentukan. Berdasarkan hasil terdapat beberapa fungsi kesantunan berbahasa ialah: (1) Fungsi deklaratif, ada kalimat penjelas, menyatakan informasi, menyatakan ucapan selamat, menyatakan sebuah perjanjian, dan menyatakan sebuah peringatan; (2) Fungsi interogatif, ada meminta pengakuan, meminta jawaban, meminta kesungguhan, meminta izin, meminta alasan, meminta keterangan, meminta pendapat, dan meminta kesungguhan; (3) Fungsi imperatif, ada menyuruh, melarang, meminta tolong, menyarankan, menganjurkan, dan menyatakan penyesalan; (4) Fungsi meminta maaf dapat dilihat dari penggunaan kata maaf dan bentuk interjeksi (ekspresi penutur); dan (5) Fungsi mengeritik, ada menolak jawaban, menyebutkan kekurangan, dan menyebut kekeliruan.
\end{abstract}

Kata kunci: Fungsi Kesantunan Berbahasa, Interaksi, Guru, Siswa

\begin{abstract}
Language politeness is a way of not giving a bad impression to the speaker or etiquette/ethics language. The formulation of the problem in this research are: (1) How is the function of language politeness in teacher and student interaction in MIS Al Jihad Palangka Raya? This study aims to describe the function of language courtesy in the interaction of teachers and students in the environment of MIS Al Jihad Palangka Raya. The approach used in research is a pragmatic approach in which this approach is suitable for understanding language usage. The type of research used is qualitative. Meanwhile, the research method is descriptive aims to obtain information about the situation and see the relation with the variables that have been determined. Based on the results there are several functions of language politeness are: (1) Declarative function, there are explanatory sentences, declaring information, expressing congratulations, declaring a covenant, and declaring a warning; (2) Interrogative function, requesting an answer, asking for sincerity, asking permission, asking for reasons, asking for information, asking for opinions, and asking for sincerity; (3) imperative function, there enjoin, prohibit, ask for help, suggest, advocate, and express regret; (4) The apology function can be seen from the use of the word sorry and the form of interjection (speaker expression); and (5) Criticism, there is rejecting the answer, mentioning deficiencies, and calling error.
\end{abstract}

Keywords: Language Speech Function, Interaction, Teachers, Students

\section{PENDAHULUAN}

Manusia tidak pernah lepas dengan yang namanya interaksi ataupun komunikasi karena kehidupan manusia selalu dalam kelompok dan selalu membutuhkan manusia yang satu dengan yang lainnya. Untuk melakukan interaksi dan komunikasi bahwasanya manusia tidak pernah luput dari sebuah baha karena bahasa tidak hanya 
berfungsi sebagai alat komunikasi untuk menyampaikan pesan. Tetapi bahasa juga sebagai alat bernalar, alat berasa, dan bahkan alat berbudaya. Seseorang akan dapat mengukur tingkat kecendikiaan manusia lainnya hanya dari sebuah bahasa yang digunakan seseorang. Parameter berbahasa inilah yang biasanya disebut dengan tatakrama atau kesopanan dalam berbahasa. Kesopanan dapat pula dikatakan sebagai prilaku yang menghormati orang lain. Dalam kehidupan sehari-hari kita tidak pernah lepas akan interaksi baik itu berinteraksi dilingkungan masyarakat maupun di lingkungan pemerintahan ataupun dilingkungan pendidikan seperti di sekolah. Agar sebuah interaksi atau komunikasi terjadi dengan baik maka seseorang harus memperhatikan tatacara dalam berkomunikasi agar tidak menyinggung dan atau menyakiti perasaan orang lain. Hal semacam ini biasanya disebut dengan kesantunan berbahasa.

Berbahasa santun sangat penting diperhatikan karena dengan begitu seseorang telah menunjukkan sikap penghargaannya kepada orang lain serta memperlakukan manusia sebagaimana seharusnya manusia. Kehidupan yang harmonis antarindividu dalam masyarakat akan sulit tercapai jika anggota-anggota masyarakat tersebut tidak memiliki etika dan sopan santun berbahasa. Kasus-kasus perkelahian yang sering terjadi baik itu antarindividu, antarkelompok, bahkan antarkampung dikarena ketidaksantunan dalam berbahasa. Oleh karena itu, kesantunan berbahasa ini perlu ditanamkan sejak dini khusus pada anak-anak yang belum mengerti etika atau yang sudah mengerti etika atau tatakrama karena penanaman nilai kesopanan sangat baik diajarkan sejak dini. Adapun yang menjadi objek penelitian ini adalah di lingkungan MIS Al Jihad Palangka Raya. Sedangkan, rumusan masalah ialah: bagaimana fungsi kesantunan berbahasa dalam interaksi guru dan siswa di lingkungan MIS AI Jihad Palangka Raya.

Yule, (2006: 82) mengatakan bahwa "kesantunan ini biasa disebut 'tatakrama'. Kesantunan dalam suatu interaksi, dapat didefinisikan sebagai alat yang digunakan untuk menunjukkan kesadaran terhadap muka orang lain. Dalam pengertian ini, kesantunan dapat dilakukan dalam situasi-situasi jarak atau kedekatan sosial. Selain itu, Fraser (dalam Chaer, 2010:47) berpendapat bahwa "kesantunan itu adalah properti yang diasosiasikan dengan tuturan dan di dalam hal ini menurut pendapat si lawan tutur, bahwa si penutur tidak melampaui hak-haknya atau tidak mengingkari dalam mematuhi kewajibannya".

Chaer, (2010: 79) mendifinisikan "fungsi kesantunan berbahasa terbagi menjadi lima, yaitu fungsi menyatakan (deklaratif), fungsi menanyakan (interogatif), fungsi menyuruh (imperative) termasuk fungsi melarang, fungsi meminta maaf, dan fungsi mengkritik". Dilihat dari fungsi lawan tutur adalah fungsi komentar, fungsi menjawab, fungsi menyetujui termasuk fungsi menolak, fungsi menerima atau menolak maaf dan fungsi menerima atau menolak kritik. Untuk lebih jelas akan diuraikan berikut ini mengenai fungsi kesantunan berbahasa.

\section{Fungsi Menyatakan (Deklaratif)}

Fungsi menyatakan di dalam kajian pragmatik dilakukan dalam bentuk kalimat deklaratif, yakni kalimat yang hanya menyampaikan berita atau kabar tentang keadaan disekeliling penutur (Chaer, 2010:80). Kalimat deklaratif umumnya 
digunakan untuk membuat pernyataan sehingga isinya merupakan berita informasi tanpa mengharapkan responsi tertentu. Namun, bukan berarti lawan tutur tidak boleh mengomentarinya. Komentar bisa saja disampaikan sehubungan dengan informasi tuturan yang disampaikan penutur.

\section{Fungsi Menanyakan (Interogatif)}

Fungsi menanyakan dilakukan dengan bentuk kalimat bermodus interogatif. Dalam kalimat menanyakan dibentuk untuk mendapatkan responsi berupa jawaban. Secara formal kalimat interogatif ditandai kata tanya (?) pada bahasa tulis dan ditandai oleh kehadiran kata tanya seperti apa, siapa, berapa, kapan dan bagaimana dengan atau tanpa partikel -kah sebagai penegas (Alwi, 2003:353).

\section{Fungsi Memerintah (Imperatif)}

Fungsi memerintah dituturkan dalam kalimat bermodus imperatif. Kalimat perintah adalah kalimat yang bertujuan memberikan perintah kepada orang lain untuk melakukan sesuatu. Dalam bentuk lisan, kalimat perintah ditandai dengan intonasi tinggi, sedangkan dalam bentuk tulisan kalimat imperatif biasanya diakhiri dengan tanda seru (!). Dardjowidjojo, (2003:105) mengatakan bahwa "kalimat perintah atau imperatif umumnya mewakili tindak ujaran direktif yang langsung. Pada umumnya respons terhadap tindak ujaran ini berupa perbuatan untuk melakukan sesuatu". Fungsi kalimat imperatif terbagi atas tiga bagian, yaitu fungsi menyuruh, fungsi melarang, dan fungsi menyetujui dan menolak.

\section{Fungsi Meminta Maaf}

Fungsi meminta maaf biasanya dilakukan oleh penutur atau lawan tutur karena penutur atau lawan tutur merasa punya kesalahan atau telah dan akan melakukan 'ketidak nyamanan' terhadap mitra tuturnya. Di dalam bahasa Indonesia hanya ada sebuah kata untuk meminta maaf, yaitu kata maaf. Penggunaan kata maaf di dalam tindak tutur meminta maaf dalam bahasa Indonesia biasanya disertai dengan kata (kategori) fatis, seperti ya; dan kata interjeksi, seperti wah, dan aduh; serta penggunaan kata sapaan seperti Bapak dan lbu.

\section{Fungsi Mengeritik}

Mengeritik berarti menyebutkan keburukan, kekurangan, kekeliruan, atau kesalahan seseorang. Tuturan mengeritik bisa mengancam muka negatif lawan tutur kalau dilakukan secara lugas. Oleh karena itu, untuk menghindari pelanggaran muka negatif, lawan tutur kita harus menggunakan kalimat berputar, yang memberi dampak lebih santun daripada tuturan yang dikemukakan secara lugas. Dalam kesantunan berbahasa tidak hanya terdapat fungsi dari penutur melainkan juga dapat dilihat dari lawan tutur, yaitu fungsi komentar, fungsi menjawab, fungsi menyetujui, fungsi menolak, fungsi menerima atau menolak maaf, dan fungsi menerima atau menolak kritik (Chaer, 2010:79)

\section{METODOLOGI}

Pendekatan yang digunakan dalam penelitian Fungsi Kesantunan Berbahasa dalam interaksi guru dan siswa di lingkungan MIS Al Jihad Palangka Raya adalah pendekatan pragmatis yang mana pendekatan ini cocok untuk memahami pemakaian bahasa. Karena dalam menganalisis sebuah kesantunan berbahasa dalam interaksi haruslah mempertimbangkan konteks tempat dan waktu terjadinya interaksi tersebut. Seperti yang telah dipaparkan Levinson (1983 dalam Nababan, 
1987:2-3) bahwa "pragmatik adalah ilmu yang mengkaji hubungan bahasa dan konteks yang mendasari penjelasan pengertian bahasa".

Jenis penelitian yang digunakan dalam penelitian ini adalah kualitatif. Jenis penelitian ini digunakan karena pendekatan ini memiliki karakteristik (1) menggunakan latar alamiah sebagai sumber data, (2) bersifat deskriptif, (3) lebih mementingkan proses daripada hasil, (4) menggunakan analisis data secara induktif, dan (5) menekankan kebermaknaan (Bogdan dan Biklen, dalam Djajasudarma, 1993). Selain itu, Moleong, (2007:6) menjelaskan bahwa "penelitian kualitatif adalah penelitian yang digunakan untuk memahami fenomena tentang apa yang dialami oleh subjek penelitian secara holistik dengan cara deskriptif dalam bentuk kata-kata dan bahasa pada suatu konteks, khususnya yang alamiah dengan memanfaatkan berbagai metode alamiah". Penelitian ini berupaya mendeskripsikan data yang diperoleh dari hasil interaksi guru dengan siswa, siswa dengan siswa, dan guru dengan guru di MIS Al Jihad Palangka Raya. Sedangkan metode penelitian adalah metode deskriptif untuk mendeskripsikan fungsi kesantunan berbahasa dalam interaksi di lingkungan MIS Al Jihad Palangka Raya. Dalam metode deskriptif ini bertujuan untuk memperoleh informasi-informasi mengenai keadaan dan melihat kaitannya dengan variable-variabel yang telah ditentukan (Mardalis, 1990:26). Dalam kajiannya, metode deskriptif menjelaskan data atau objek secara natural, objektif, dan faktual (apa adanya) (Arikonto, 1993: 310). Data dalam penelitian ini, berupa tuturan yang dituturkan oleh guru dan siswa, guru dan guru, siswa dan siswa pada saat melakukan interaksi di lingkungan MIS AI Jihad, sedangkan sumber data adalah guru dan siswa dari kelas 1 dan VI di MIS Al Jihad Palangka Raya. Arikonto, (2005:100) menyebutkan bahwa "teknik pengumpulan data adalah cara-cara yang digunakan peneliti untuk mengumpulkan data". Teknik pegumpulan data yang digunakan dalam penelitian ini adalah teknik rekaman, teknik simak, dan teknik catatan pengamatan.

\section{HASIL DAN PEMBAHASAN}

\section{Fungsi Deklaratif (Menyatakan)}

(1) S: Ibu, maaf. Ini tabungannya ada yang ketinggalan dicatat.

(lbu, maaf. Tabungannya ada yang ketinggalan dicatat)

G: Oh iya. Tabungan yang kemaren ya.

(Oh ia. Tabungan yang kemarin)

Konteks: Pada saat nominal tabungan siswa ada yang tidak sesuai.

Tuturan pada kalimat (1) di atas berfungsi sebagai kalimat penjelas seperti yang terlihat pada kutipan "Ibu, maaf. Ini tabungannya ada yang ketinggalan dicatat" (Ibu, maaf. Tabungannya ada yang ketinggalan dicatat). Kalimat penjelas ini dapat dikatakan santun karena dalam tuturan si siswa (S) terdapat penggunakan kata "maaf' untuk menyatakan sebuah kekeliruan kepada si guru.

(2) G: ...sebelumnya ibu ucapkan selamat ya Ajihad, sudah memperoleh juara umum...

(... sebelumnya Ibu ucapkan selamat Aljihad, sudah memperoleh juara umum)

Konteks: Guru mengucapkan selamat pada siswa yang memperoleh juara drum band.

Tuturan pada kalimat (2) berfungsi untuk menyatakan ucapan selamat atas keberhasilan siswanya. Ucapan selamat pada kalimat di atas ditandai pada penggunaan kata "selamat" dan 
disertai dengan mimik wajah si guru $(G)$ yang menunjukkan rasa gembira atas keberhasilan siswanya.

(3) G: Coba perhatikan Bapak dulu. Lain kali, yang tidak mengumpulkan tugasnya, Bapak tidak akan memberikan toleransi lagi kecuali dengan alasan yang tepat.

Konteks: Pada saat ada beberapa siswa yang tidak mengerjakan tugas.

Tuturan pada kalimat (3) di atas berfungsi untuk menyatakan sebuah peringatan kepada siswasiswanya yang tidak mengerjakan tugasnya di rumah. Kalimat pernyataan ini dapat dikatakan santun karena dalam menyampaikan sebuah peringgatan si guru menggunakan bahasa yang halus, seperti yang terlihat pada penggunaan kata "coba perhatikan" dan penggunaan kata saapaan "Bapak" untuk meminta siswa-siswi meperhatikan saat ia bicara.

\section{Fungsi Interogatif (Menanyakan)}

(4) S: Bapak, mau tanya pak, boleh ngga, Pa? (Peserta didik mengangkat tangan) (Bapak, saya mau tanya pak. Boleh tidak?) Konteks : Pada saat guru sedang menjelaskan pelajaran.

Tuturan pada kalimat (4) berfungsi untuk meminta izin. Fungsi meminta izin ini dituturkan oleh siswa kepada si guru untuk meminta izin sebelum ia bertanya. Oleh karena itu, tuturan tersebut dikatakan santun karena si siswa tidak langsung tertanya melainkan meminta izin sebelum bertanya seperti yang terlihat pada kutipan "mau tanya pak, boleh ngga, Pak?". Selain itu, si siswa juga memberikan opsi sambil mengacungkan jari sebelum bertanya agar si guru tidak merasa terganggu saat menjelaskan pelajaran.

(5) G: Kenapa baru datang sayang?
(Kenapa baru datang sayang?)

Konteks : Pada saat ada siswa yang telat masuk.

Tuturan pada kalimat (5) berfungsi untuk meminta alasan. Dalam tuturan yang dituturkan si guru $(G)$ pada kalimat (5) di atas dapat dikatakan santun karena si guru meminilkan kecaman terhadap siswanya. Hal ini tampak pada kutipan "Kenapa baru datang sayang?" dalam kutipan ini tampak jelas bahwa tuturan tersebut diperhalus karena ada penggunaan kata "sayang" untuk meminta alasan kepada siswanya atas terlambat.

(6) G: Siapa yang bawa air?

(Siapa membawa air)

S: Saya, Pak.

Konteks : Pada saat ada air yang tumpah.

Tuturan pada kalimat (6) berfungsi untuk meminta pengakuan kepada siswa-siswinya. Dalam kalimat tanya meminta sebuah pengakuan ini dituturkan si guru karena ada air yang tumpah di bawah meja. Tuturan si guru $(G)$ dapat dikatakan santun karena tuturan tersebut menggunakan tuturan tidak langsung untuk menanyakan siapa yang menumpahkan air tersebut. Kalimat tidak langsung ini dituturkan agar siswa tidak merasa tertekan sehingga mereka akan terbuka mengakuinya.

\section{Fungsi Imperatif (Memerintah)}

(7) G: Coba hari ini siapa yang gak, (guru memberhentikan pembicaraan) Alfin, ih Alfin udah ganteng 100

(Coba hari ini siapa yang gak,(guru memberhentikan pembicaraan) Alfin, Alfin sudah ganteng)

S: Wah...(serentak)

Konteks : Pada saat guru menjelaskan namun ada siswa yang ribut. 
Tuturan pada kalimat (7) berfungsi untuk melarang, yang dituturkan si guru kepada siswanya pada saat siswa sedang ribut. Tuturan ini diaggap santun karena tuturan si guru menggunakan bahasa yang tidak langsung. Penggunaan kalimat "... Alfin, ih Alfin udah ganteng loo" terdengar sebagai pujian namun makna dari tuturan tersebut berfungsi untuk melarang si anak agar tidak ribut saat guru menjelaskan pelajaran.

(8) G: Tolong angkatkan kursinya Maimunah, ke depan sini sayang.

(Tolong angkatkan kursinya Maimunah, ke depan sini sayang.)

Konteks : Pada saat guru meminta siswa pindah ke depan.

Tuturan pada kalimat (8) berfungsi untuk meminta tolong yang dituturkan guru kepada siswanya saat si guru menyuruh siswa pindah tempat duduk. Dalam kalimat perintah yang berfungsi sebagai kalimat meminta tolong ini dapat dikatakan santun karena ditandai pada penggunaan kata "tolong" dan kata "sayang". Penggunaan "tolong" dan kata "sayang" membuat kalimat perintah terdengan lebih halus dan santun.

\section{Fungsi Meminta Maaf}

(9) S: Aduh, kada sengaja.

(Aduh, tidak sengaja)

Konteks : Pada saat siswa menyenggol bahu temannya.

Tuturan (9) ini berfungsi untuk menyatakan sebuah penyesalan pada saat siswa menyenggol bahu temannya. Dalam kalimat tersebut dapat dikatakan santun karena ditandai pada penggunaan interjeksi "aduh". Penggunaan interjeksi ini merupakan bentuk dari ungkapan sesal si penutur bahwa ia tidak sengaja menyenggol bahu temannya meskipun si penutur (S) tidak menggucapkan kata maaf namun dapat dilihat dari ekspresi dan penggunaan kata interjeksi tersebut.

(10) S: Maaf, Bu, mau minta izin ke WC.

(Maaf, Ibu, Saya mau minta izin ke WC)

Konteks : Pada saat siswa minta izin ke WC.

(11) S: Maaf pak Rois, itu ada yang nangis.

(Maaf bapak Rois, itu ada yang menangis)

Konteks : Pada saat hendak melaksanakan shalat duha.

Tuturan pada kalimat (10) dan (11) di atas berfungsi sebagai kalimat meminta maaf. Dalam kalimat (10) dituturkan siswa kepada gurunya untuk meminta maaf pada saat meminta izin keluar (toilet). Sedangkan, dalam kalimat (11) dituturkan siswa kepada si guru pada saat si guru hendak melaksanakan shalat. Tuturan (10) dan (11) dapat dikatakan santun karena ditandai pada penggunaan kata "maaf' seperti yang terlihat pada tuturan di atas. Penggunaan kata "maaf' dalam kalimat (10) dituturkan agar si guru tidak merasa diberhentikan dengan mendadak saat sedang menjelaskan. Sedangkan penggunaan kata "maaf' pada kalimat (11) dituturkan siswa pada saat mengganggu gurunya yang hendak melaksanakan shalat duha.

\section{Fungsi Mengeritik}

(12) G: la, jawabannya sudah cukup bagus namun ada bagian-bagian yang tidak tepat...

Konteks : Pada saat guru mengomentari jawaban siswa.

Tuturan pada kalimat (12) berfungsi untuk menolak jawaban. Dalam tuturan ini dituturkan guru kepada siswanya saat memberi komentar atas jawaban siswanya. Dilihat dari jawaban yang diberikan siswa dapat dikatakan bahwa jawaban tersebut tidak ada satupun yang berkaitan dengan pertanyaan guru. Namun, pada saat si guru (G) 
mengkritik jawaban siswanya dapat dikatakan santun karena tuturan si guru $(G)$ tidak langsung mencap bahwa jawaban siswanya itu salah, tetapi si guru tetap memberikan pujian seperti kutipan "la, jawabannya sudah cukup bagus". Dalam kutipan ini sudah terlihat jelas bahwah si guru $(G)$ tidak mau menjatuhkan siswanya dihadapan siswa yang lainnya. Meskipun jawabannya tidak tepat namun si guru tetap memuji si siswa seperti yang ditandai pada penggunaan kata "bagus".

(13) S: Sudah sangat bagus, Bu. Cuma suaranya kurang keras aja.

(Sudah sangat bagus, Bu. Cuman suaranya kurang jelas saja)

Konteks: Pada saat si siwa mengomentari penampilan temannya yang lain.

Tuturan pada kalimat (13) berfungsi untuk menyebutkan kekurangan orang lain. Dalam kalimat kritik yang menyebutkan kekurangan orang lain ini dapat dikatakan santun karena tuturan si siswa (S) diperhalus menggunakan kata "sangat" (sangat bagus). Penggunaan kata sangat ini berfungsi untuk melebih-lebihkan pujian agar lawan tutur atau orang yang dikomentari tidak merasa rendah dihadapkan orang lain.

\section{KESIMPULAN}

Kesantunan berbahasa merupakan bagian dari adab atau tatakrama yang membedakan tingkat kecendikiaan antara individu yang satu dengan yang lainnya. fungsi dari kesantunan berbahasa terdiri dari lima bagian, yaitu deklaratif, interogratif, imperatif, meminta maaf, serta mengeritik. Fungsi deklaratif (menyatakan), yaitu fungsi kalimat penjelas yang diperhalus dengan kata "maaf", fungsi menyatakan ucapan selamat yang ditandai pada penggunaan kata "selamat", dan fungsi menyatakan sebuah peringatan yang diperhalus dengan kata "coba". Fungsi interogatif (menanyakan), yaitu fungsi meminta pengakuan yang diperhalus dengan penggunaan kalimat tidak langsung, fungsi meminta izin yang diperhalus dengan pemberian opsi, dan fungsi meminta alasan diperhalus dengan kata "sayang". Fungsi imperatif (memerintah), yaitu fungsi melarang diperhalus menggunakan kalimat pujian, dan fungsi meminta tolong yang diperhalus dengan penggunaan kata "tolong". Fungsi meminta maaf dapat dilihat dari penggunaan kata maaf dan bentuk interjeksi (ekspresi penutur). Fungsi mengeritik, yaitu fungsi menolak jawaban, fungsi menyebutkan kekurangan, dan fungsi menyebut kekeliruan. Dari ketiga fungsi ini diperhalus dengan penggunaan kalimat pujian.

\section{DAFTAR PUSTAKA}

Alwi, H. 2003. Tata Bahasa Baku Bahasa Indonesia. Jakarta: Balai Pustaka.

Arikonto, S. 1993. Prosedur Penelitian: Suatu Pendekatan praktek. Jakarta: Rineka Cipta.

Arikonto, S. 2005. Dasar-dasar Evaluasi Pendidikan. Jakarta: Bumi Jakarta.

Chaer, A. 2010. Kesantunan Berbahasa. Jakarta: Rineka Cipta.

Dardjowidjojo, S. 2003. Psikolinguistik Pengantar Pemahaman Bahasa Manusia. Jakarta: Yayasan Obor Indonesia.

Djajasudarma, F. 1993. Metode Linguistik Ancangan Metode Penelitian dan Kajian. Bandung: PT Eresco.

Mardalis. 1990. Metode Penelitian; Suatu Perkenalan Proposal. Jakarta: PT. Melton Putra.

Moleong, L.J. 2007. Metodologi Penelitian Kualitatif. Bandung: Remaja Rosdakarya. 
Nababan, P. W. J. 1987. Ilmu Pragmatik (Teori dan

Penerapannya). Malang: IKIP Malang.

Yule, G. 1996. Pragmatik. Terjemahan oleh Indah Fajar Wahyuni. 2006. Yogyakarta: Pustaka Pelajar. 